\title{
A METHOD FOR THE DESIGN OF A CONTINUOUS MICROALGAE CULTURE PHOTOBIOREACTOR IN SERIES WITH RECIRCULATION SYSTEM
}

\author{
METODO PARA EL DISEÑO DE FOTOBIOREACTORES CONTINUOS EN SERIE \\ CON RECIRCULACIÓN PARA CULTIVO DE MICROALGAS
}

\author{
MÉTODO PARA O DESENHO DE FOTOBIOREATORES CONTINUOS EM SÉRIE COM \\ RECIRCULAÇÃO PARA CULTURA DE MICROALGAS
}

\author{
Sandra Vargas ${ }^{1}$; César-Augusto Gómez-Pérez ${ }^{1 *}$ and Jairo Espinosa ${ }^{1}$ \\ 'Grupo de Automática de la Universidad Nacional GAUNAL. Universidad Nacional de Colombia. \\ Facultad de Minas. Medellin. Colombia \\ e-mail: cagomez@unal.edu.co
}

(Received: Feb. 08, 2016; Accepted: Aug. 20, 2017)

\begin{abstract}
T owadays, there are functional pilot scale PhotoBioReactors (PBRs), which present serious challenges when performing a scaling up process for an industrial application. The aim of this research was to evaluate the design of several continuous flat plate PBRs connected in series, while allowing constant circulation from the last to the first unit. Scaling up feasibility using the adjunction of new units, instead of PBRs volume increase is analyzed. An ad hoc mathematical model based on mass balances and constitutive equations from literature was constructed; the model integrates the illumination and mass transfer effects on microalgae growth kinetics by a complete model solution. Unfortunately, the model is too complex to be analyzed by conventional methods. Furthermore, it presents problems when evaluated by numeric methods as the results do not have physical meaning and the initial condition has strong effect on the final solution. Hence, this paper presents a simple method to analyze the design of this kind of continuous system. The method allows the design parameters calculation of PBRs system resulting physically in a simple way without having to guess possible system solutions. Moreover it is also shown that the continuous PBRs in series with a recirculation system obtain good amount of microalgae productivity.
\end{abstract}

Keywords: Continuous photobioreactor design, Mathematical model, Carbon Dioxide fixation, Mass transfer, Illumination regime.

How to cite: Vargas, S., Gómez- Pérez, César, A., Espinosa, J. (2017). A method for the design of a Continuous Microalgae culture Photobioreactor in series with recirculation system. CT\&F - Ciencia, Tecnología y Futuro, 7(1), 101 - 116.

*To whom correspondence should be addressed 


\section{RESUMEN}

oy en día, existen fotobiorreactores (PBRs de su sigla en inglés) a escala piloto funcionales, que
presentan serios desafíos al momento de realizar un proceso de escalamiento para una aplicación
industrial. Este trabajo propone evaluar el diseño de varios fotobiorreactores continuos de placa plana
conectados en serie con recirculación desde la última unidad hasta la primera, para analizar la viabilidad
del escalado de la productividad a partir de la adición de más unidades en lugar de incrementar el volumen
del fotobiorreactor. Para esto, se ha construido un modelo matemático basado en los balances de masa y
ecuaciones constitutivas de la literatura, en las cuales se integran los efectos de la iluminación y la transferencia
de masa en la cinética de crecimiento de las microalgas. Desafortunadamente, se obtiene un modelo que es
muy complejo para evaluar por medios convencionales. Adicionalmente, presenta problemas al evaluarse
por métodos numéricos ya que se obtienen resultados que no tienen explicación física y la solución tiene
una gran dependencia de las condiciones iniciales. Por lo tanto, este artículo presenta un método sencillo
para el análisis del diseño de este tipo de sistema continuo. El método permite obtener los parámetros de
diseño del sistema de fotobiorreactores y soluciones con sentido físico de una forma sencilla, sin tener que
tantear las posibles soluciones del sistema. Adicionalmente se muestra que el sistema de fotobiorreactores
continuos en serie con recirculación proporciona una buena productividad de microalgas.

Palabras clave: Diseño de fotobiorreactores continuos, Modelo matemático, Fijación del Dióxido de Carbono, Transferencia de masa, Régimen de iluminación

\section{RESUMO}

tualmente existem fotobioreatores de escala piloto funcionais, porém trazem sérias complicações
para executar um processo de escalonamento para uma implementação industrial. Este trabalho
propõe avaliar a concepção de vários fotobioreatores contínuos de placa plana conectados em série
com recirculação desde a última unidade até a primeira, para analisar a viabilidade do escalonamento da
produtividade a partir da adição de mais unidades em vez de aumentar o volume do fotobioreator. Para este
propósito um modelo matemático foi construído baseado nos balanços de massa e equações constitutivas
da literatura, nas quais se integram os efeitos da iluminação e a transferência de massa na cinética de
crescimento das microalgas. Infelizmente, obtém-se um modelo que é muito complexo para ser avaliado
através de meios convencionais. Além disso, apresenta problemas ao ser avaliado com métodos numéricos,
há que se obtêm resultados que não têm explicação física e a solução tem uma grande dependência das
condições iniciais. Portanto, este artigo apresenta um método simples para a análise do desenho deste
tipo de sistema contínuo. O método permite obter os parâmetros do desenho do sistema de fotobioreatores
e soluções com sentido físico de forma simples, sem ter que tentar possíveis soluções do sistema. Além
disso, mostra-se que o sistema de fotobioreatores contínuos em série com recirculação oferece uma boa
produtividade de microalgas.

Palavras-chave: Desenho de fotobioreatores contínuos, Modelo matemático, Fixação do Dióxido de Carbono, Transferência de massa, Regime de iluminação 


\section{INTRODUCTION}

Recently, microalgal culture has been acquiring special interest (Breuer, Lamers, Janssen, Wijffels \& Martens, 2015), since microalgae can fix atmospheric carbon dioxide promoting the mitigation of the greenhouse effect. Additionally, interesting products such polyunsaturated fatty acids, biofuels and pigments could be obtained. Nowadays, PBR research is prevalent in order to obtain efficient and reliable culturing (Breuer et al., 2015). Moreover, continuous microalgae production in PBR will be a good prospect for technology, because it prevents culture contamination, avoiding uploading and downloading times. It also controls important process variables. This technology allows to reach major productivity and a quality final product (Bouallagui, Touhami \& Hanafi, 2013). However, as a disadvantage, continuous PBRs make it difficult to achieve a reliable scale up with a strong effect on productivity and uncertainty about this effect (Molina Grima, Acién Fernández, García Camacho, Camacho Rubio, Chisti, 2000; García Camacho, Gallardo Rodríguez, Sánchez Mirón \& Belarbi, 2011; Quinn, Turner \& Bradley, 2015; Fernández, Mota, Teixeira \& Vicente, 2015). Furthermore, the PBR construction and operation are very expensive (Lehr \& Posten, 2009).

Nowadays, Microalgae culture production in PBR is performed using batch processes (Bosma et al., 2014). However, continuous operation would improve the culture performance because process variables can be controlled, productivity will increase and the risk of contamination is reduced (Gadkar, Doyle, Crowley \& Vamer, 2003). Unfortunately, the implementation of continuous PBR constitutes a difficult challenge, because it needs large scale PBR units to obtain a feasible product flow and PBRs units' productivity dramatically varies due to the scale up process (García Camacho et al., 2011). On the other hand, feasible PBRs design provide opportunity for the use of highly reliable mathematical models, since it takes into account the interactions between several phenomena (Posten, 2009; Fernández, Acién, Berenguel \& Guzmán, 2014).

Microalgae grow is based on the photosynthesis process (Basanti \& Gualtieri, 2006), where chemical kinetics is governed by the way the microalgae harvest photons and Carbon Dioxide. The gathering of light depends on the light source and the way it penetrates the PBR medium (Janssen, Tramper, Mur \& Wijffels, 2002). Carbon dioxide fixation depends on a mass transfer from the gas phase to the medium and the aeration system (Molina Grima, Acién Fernández, García Camacho \& Chisti, 1999). PBR design is characterized because it requires multiphenomena analysis. The importance of illumination and carbon dioxide fixation is well known. PBR design was worked fundamentally by understanding illumination (Janssen et al., 2002; Molina Grima et al., 1999; Molina Grima, García Camacho, Sanchez Pérez, Acién Fernández \& Fernández Sevilla, 1997; Carvalho, Silva, Baptista \& Malcata, 2011; Kommareddy \& Anderson, 2003; Kommareddy \& Anderson, 2004; Acién Fernández, Fernández Sevilla, Sánchez Pérez, Molina Grima \& Chisti, 2001) and some authors take into account mass transfer (Molina Grima et al., 1999; Carvalho \& Malcata, 2001; Sierra, Acién, Fernández, García, González \& Molina Grima, 2008). However their methods did not take into account the interactions between variables, which could be very important for the process because if the interactions are not taken into account, the process design will have a great uncertainty, difficult to evaluate. Kurano \& Miyachi (2005) describes a growth kinetic model that takes into account two variables (illumination and carbon source) using Chlorococcum littorale. In this research principle mathematical models were used to evaluate interactions between variables analyzing the continuous PBR design. However, a nonlinear mathematical model with multiple variables interaction is complex to analyze. Moreover, it is necessary to use numerical methods and the solutions have strong effect on the initial conditions. However some solutions do not have physical meaning. Hence, this paper presents a design methodology of continuous flat plate PBRs in series with recirculation system.

The methodology is based on the splitting of the mathematical model in a simple set of linear equations and a set of nonlinear equations. Iterative algorithm allows the convergence to a solution. Additionally, it uses previous knowledge to lead the results to a physical feasible solution. This paper analyses the possibility to design a series of continuous flat plate PBR with recirculation from the last unit to the first one, using a complex model with interactions between variables, and based on a mathematical model that takes into account variables associated with illumination and mass transfer. 
The results seek to evaluate the feasibility of the design analysis. To present the method, a brief description of the continuous PBR process is described in section 2, and then the mathematical model is depicted in section 3 . Section 4 shows the PBR design methodology followed by the results and main conclusions.

\section{EXPERIMENTAL DEVELOPMENT}

\section{Continuous PBR Cultivation Description.}

Figure 1 shows a graphic description of the continuous flat plate PBR. In recent times, this kind of reactor have received great attention for microalgae cultivation because of its wide area of illumination, its lower oxygen accumulation compared to other structures and its good capacity for microalgae mobilization (Sierra et al., 2008). Furthermore, a series of flat plate PBRs units is considered, because it is required to analyze whether the system can improve its performance when several PBRs are used or not (Figure 2). The number of flat plate PBRs described in this series will be a design variable.

Each flat plate PBR has an independent aeration system using a carbon dioxide and air mix; it is assumed that the partial pressure of carbon dioxide in the feeding air is known. The liquid level of the reactors is controlled by overflowing. Agitation is guaranteed by the aeration system. The complete system has a recirculation flow that connects the last reactor with the first one. Also it is supposed that each reactor is completely well agitated, then, radial or axial gradients into each reactor are not considered.

Chlorococcum littorale microalgae have reported growth kinetics depending on light intensity and carbon dioxide concentration. This microalgae was selected for culture. Light intensity and Carbon Dioxide concentration are critical conditions processes in the reactor design because they could relate photons with carbon dioxide mass transfer and growth kinetics (Kurano \& Miyashi, 2005). The temperature was kept constant at $25^{\circ} \mathrm{c}$, also $\mathrm{pH}$ level at 5.5, and illumination was assumed artificial, therefore the irradiance intensity was continuous and constant with a value of $0.7 \mathrm{kw} / \mathrm{m} 2$.

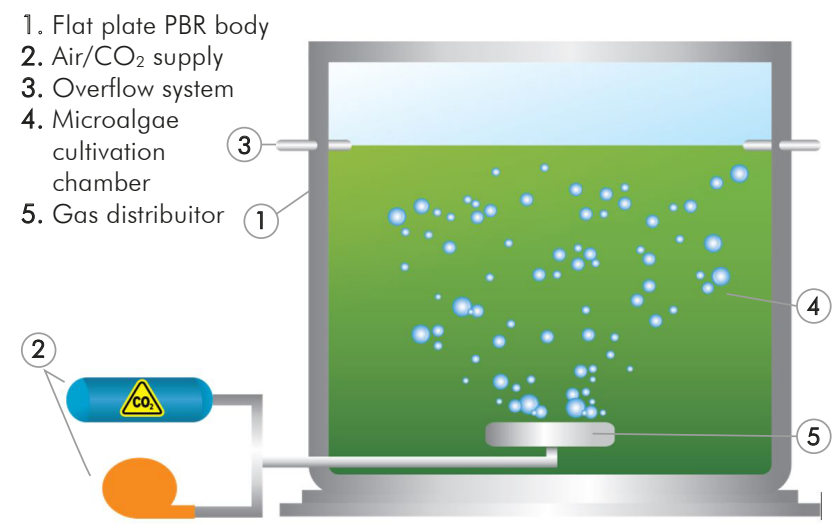

Figure 1. Flat plate photobioreactor unit.

\section{Mathematical Model.}

Two different systems could be identified on each PBR: the liquid medium (SI) and the air (SII) with carbon dioxide. The following equations show the mass balances of the liquid medium.

For system SI the material balance for the biomass is:

$$
\frac{d X}{d t}=X \cdot(\mu-D)+D X_{i n}
$$

Where $X$ is the biomass concentration inside the bioreactor, $X_{i n}$ is the feed biomass concentration at the in-flow of the reactor, $\mu$ is the specific growth rate, $\mathrm{D}$ is the dilution rate which is given by $D=F / V$, where $F$ is the liquid medium flow and $V$ is the PBR work volume.

For the same system, substrate balance is:

$$
\frac{d C_{\mathrm{CO}_{2}}}{d t}=D C_{\mathrm{CO}_{2}{ }^{i n}}-D C_{\mathrm{CO}_{2}}-\frac{\mu X}{Y_{\mathrm{X} / \mathrm{CO}_{2}}}+K_{\mathrm{L}} a \cdot\left(C_{\mathrm{CO}_{2}}{ }^{*}-C_{\mathrm{CO}_{2}}\right)
$$

Where $C_{\mathrm{CO}_{2} \text { in }}$ is the carbon dioxide concentration at the inflow of the bioreactor, $\mathrm{C}_{\mathrm{CO}_{2}}$ is the carbon dioxide concentration in the reactor and it is assumed that the same concentration comes out in the outflow, $K_{L} a$ is the constant of the mass transfer, $\mathrm{C}_{\mathrm{CO}_{2}}{ }^{*}$ is the concentration of $\mathrm{CO}_{2}$ in equilibrium, $Y_{X / \mathrm{CO}_{2}}$ is the biomass $/ \mathrm{CO}_{2}$ consumed yield.

As for system SII, (in this case is $\mathrm{CO}_{2}$ enriched air), the $\mathrm{CO}_{2}$ component balance can be represented as: 


$$
\frac{d C_{\mathrm{CO}_{2} \mathrm{~g}}}{d t}=\frac{F_{\mathrm{g}}}{V_{\mathrm{g}}}\left(C_{\mathrm{CO}_{2} \mathrm{gin}}{ }^{-} C_{\mathrm{CO}_{2} \mathrm{~g}}\right)-K_{\mathrm{L}} a \cdot\left(C_{\mathrm{CO}_{2}}{ }^{*}-C_{\mathrm{CO}_{2}}\right)
$$

Where $F_{g}$ is the flow of gas (carbon dioxide), $V_{g}$ is the volume of gas, $\mathrm{C}_{\mathrm{CO}_{2} \text { gin }}$ and $\mathrm{C}_{\mathrm{CO}_{2} \mathrm{~g}}$ is the concentration of carbon dioxide in the gas in the inlet and outlet respectively.

Equations 1 to 3 can be used for all the PBR units of the whole process. It means the number of unit's equations must be solved simultaneously, increasing the analysis complexity. Material balances are the fundamental equations to design the PBR, but certain parameters must be specified, therefore the model can be completed with other empirical equations.

\section{Growth Kinetics}

The growth kinetics of microalgae depends on several variables, including: the light intensity, amount of $\mathrm{CO}_{2}$ available, $\mathrm{pH}$ level, temperature, oxygen concentration, inoculum concentration, nitrogen concentration, concentration of phosphorus and other nutrients. As a result of the dependency of several factors it is difficult to find references with kinetic expressions incorporating all the variables. Therefore, dependence of the growth kinetics as a variable sensitive to the process was studied. Normally this variable is the light intensity (Carvalho et al., 2001).

In addition, irradiance is of vital importance in a PBR design because it can cause photoxidation or photoinhibition. Additionally, irradiance is not homogeneous, especially in the dense cultures (Béchet, Shilton \& Guieysee, 2013). This is because light intensity decreases exponentially as it penetrates the medium. Furthermore, the concentration of $\mathrm{CO}_{2}$ is an important requirement as this affects the $\mathrm{pH}$ level of the culture, and because $\mathrm{CO}_{2}$ acts as the only carbon source in the growth of photoautotrophic microalgae (Basanti \& Gualtieri, 2006). Some researchers also exemplify substrate kinetic behavior, called inhibition caused by $\mathrm{CO}_{2}$. The microorganism growth could be limited by both substrates. Hence a model interacting growth that takes into account the combined effect of the two variables is required, hence (Nielsen, Villadsen \& Lidén, 2003; Schügerl, Rehm, Reed, Pühler \& Stadler, 1991):

$$
\mu=\mu_{\text {max }} \cdot \frac{I_{a v}}{I_{o p t}} \cdot e^{\left(1-\frac{I_{a v}}{I_{o p t}}\right) \cdot\left(\frac{p C O_{2}}{K_{S}+p C O_{2}+\frac{p C O_{2}^{2}}{K_{i}}}\right)}
$$

Where $\mu_{\max }$ is the maximum specific growth rate, $I_{a v}$ is the light intensity expressed as the flux density of photons and $I_{o p t}$ is the light intensity at which $\mu=\mu_{\max }, \mathrm{pCO}_{2}$ is the Partial pressure of Carbon Dioxide, $K_{S}$ is the saturation constant of substrate, and $K_{i}$ is the constant inhibition. The estimated values of the parameters reported in (Kurano \& Miyachi, 2005) were $\mu_{\max }=0.134 h^{-1}, I_{\text {opt }}=505 \mathrm{~mol}$ photon $\mathrm{m}^{-2} \mathrm{~s}^{-1}, K_{s}=0.00048$ bar and $K_{l}=0.31$ bar.

The estimated optimal specific growth rate is 0.12 $h^{-1}$ at $I_{p o t}$ and $\mathrm{pCO}_{2}=0.02 \mathrm{bar}$. This is the point where the PBR should operate to obtain the best performance. The design method used this point as an initial point to seek a reliable design process.

\section{Light Regime}

The light regime is defined as the parameters and variables that characterize the light radiation received by the microalgae while they are cultured. The light must be provided at the appropriate intensity, duration and wavelength. Photons coming into microalgae harvest are the energy source for the development of the mechanism of photosynthesis. When light passes through the PBR, microalgae will absorb part of such light and transform it into chemical energy. The equation describing the absorption of light is called the Lambert-Beer Law, which states that (Greenwald, Gordon \& Zarmi, 2012):

$$
I(z)=\mathrm{I}_{0} \mathrm{e}^{-\alpha X z}
$$

Where $z$ is the depth of the flat plate PBR, $X$ is cell density of microalgae, $\alpha$ is the absorption coefficient, $I(z)$ is the irradiance at the length $z$, and $I_{0}$ is the irradiance of the light source. For the design of the PBR it is important to maintain sufficient light imposed upon the microalgae to saturate the active sites during the passage of the photon, but just enough to ensure that photoinhibition does not take place. Using the expression for the kinetics of algae growth results in an ideal irradiance is $505 \mu \mathrm{mol}$ photon $\mathrm{m}^{-2} \mathrm{~s}^{-1}$ (Kurano \& Miyachi, 2005).

The irradiance at certain depth is difficult to establish. Average radiation intensity is used to solve this problem (Molina Grima et al., 1997). This index is calculated by averaging the value of $\mathrm{I}(\mathrm{z})$ :

$I_{a v}=\frac{\mathrm{I}_{0}}{\alpha X L}\left(1-e^{-\alpha X L}\right)$ 
$\alpha$ is the medium absorbance coefficient. For the species Chlorococcum littorale the value was estimated using the settings reported in Berberiglu, Gómez \& Pilon, (2009).

\section{Mass Transfer}

In the cultivation of microalgae, it is necessary to evaluate the mass transfer of $\mathrm{CO}_{2}$ entering to the microalgae and also to know the transfer of $\mathrm{O}_{2}$ to the medium as a product gas (since $\mathrm{O}_{2}$ generates inhibition); the mass transfer along with lighting is one of the most studied phenomena in PBRs (Carvalho \& Malcata, 2001; Sierra et al., 2008; Kurano \& Miyachi, 2005). The mass transfer is improved through aeration systems and good agitation.

The study of the mass transfer allows the inclusion to assess parameters such as gassing power, gas flow, agitation, and the average bubble diameter (Sierra et al., 2008). All these parameters are designed to ensure efficient mass transfer between the gas and the liquid. The equation commonly used to evaluate the mass transfer is:

$N_{\mathrm{CO}_{2}}=K_{L} a \cdot\left(C_{\mathrm{CO}_{2}}{ }^{*} C_{\mathrm{CO}_{2}}\right)$

Where $\mathrm{N}_{\mathrm{CO}_{2}}$ is the mole flux transferred from gas to the liquid medium, the concentration of $\mathrm{CO}_{2}$ in equilibrium $\left(\mathrm{CO}_{2}{ }^{*}\right)$ according to Henry's law at $25^{\circ} \mathrm{C}$ is equal to $0.1525 \mathrm{~g} / \mathrm{lt}$. The gas volume in the reactor is estimated by the gas flow and the gas hold-up $(\varepsilon)$, this parameter is defined as:

$\varepsilon=\frac{V_{g}}{V_{g}+V}$

The gas hold-up empirical expression is obtained from the literature. Equation (9) is characterized from a flat plate unit presented in Sierra et al., (2008). Equation (9) relates the gassing power with the gas Hold-up.

$$
\varepsilon=3.32 \times 10^{-4}\left(\frac{P_{g}}{V}\right)^{0.97}
$$

Where:

$$
P_{g}=\rho_{\mathrm{L}} \mathrm{F}_{\mathrm{g}} \sqrt{\frac{V}{L}}
$$

Where, $\rho_{L}$ is the liquid density. To evaluate the mass transfer coefficient, the empirical equation proposed by

Hughmark for individual bubbles is used for microalgae culture in bubbled PBRs (Carvalho \& Malcata, 2001), and it is recommended especially when the bubbles have large diameters (over $2.5 \mathrm{~mm}$ ):

$$
K_{L} a=28.38 \frac{D_{C O 2}}{d_{B}}\left[2+0.061\left(R e_{B}\right)^{0.779}\left(\frac{\mu_{L}}{\rho_{L} D_{\mathrm{CO} 2}}\right)^{0.546}\left(\frac{d_{B} g^{0.33}}{D_{\mathrm{CO}^{2}}{ }^{0.66}}\right)^{0.116}\right](11)
$$

Where, $D_{\mathrm{CO}_{2}}$ is diffusivity of $\mathrm{CO}_{2}, \mathrm{Re}_{B}$ is the Reynolds number of the liquid, $\mu_{L}$ refers to the liquid medium viscosity, $d_{B}$ is the diameter of the bubble, $g$ is gravity and $K_{L}$ is the mass transfer coefficient.

$$
\operatorname{Re}_{B}=\frac{d_{B} V_{t} \rho_{L}}{\mu_{L}}
$$

The Reynolds number is given by equation (12) and it is associated with the bubble diameter $\left(d_{B}\right), V_{t}$ the single bubble velocity, and the density and viscosity of the liquid. The bubble diameter depends on the area between the phases and the mass transfer coefficient showing opposite dependence. As a consequence, the capture of gas was more sensitive to the bubble diameter than to the coefficient of mass (Chisti, 1989). Hence the bubble size, the gas flow rate and pressure of the $\mathrm{CO}_{2}$ should be adjusted to the requirements of each specific culture.

\section{PBR Design Methodology.}

The nonlinear system previously depicted can be solved using numerical methods, but the results have a big dependence upon initial conditions. Moreover, some results do not have physical meaning as most of them do not have a real application. Due to the previous results, this research designed a new method to avoid this problem, simplifying the solution search and obtaining a solution with physical sense. In this section a method for the design of a series of flat plate PBRs with recirculation using mathematical model is shown. The method is used to obtain the PBR dimensions, inlet flow, total flow, liquid recirculation, gas flow, and number of PBRs. A summary of the proposed method goes as follows:

ii)

Biomass concentration in PBR units with constant growth kinetics: the specific growth kinetics was assumed, such as optimum and constant. The constant growth kinetic assumption allows building the system equations and how to set linear equations which are easier to evaluate. 
iii)

Estimating the specific growth rate: Biomass concentration was used to evaluate the specific growth rate on every PBR unit using equation 6.

iv) Biomass concentration in PBR units with new growth kinetics: it was assumed that the specific growth rate was constant. But, specific growth kinetics calculated for every PBR unit in series in the third step was used to solve the linear equations system.

v) Iterate until error < tolerance: the biomass concentration was used to estimate the specific growth rate, and to calculate new biomass concentration values. Iterations were executed until the committed error was lower than a defined tolerance.

The following subsections will depict in detail the proposed method, explaining the equations used and the values obtained in each step.

\section{PBR pre-design.}

In this step, equations $1,2,3,4,6,8,9,10,11$ and 12 were solved using Newton's method and some assumptions were considered to ease the solution task, as follows :

i) Specific growth rate on each PBR unit is equal to the dilution rate at the optimal specific growth rate.

ii) The average irradiance is equal to the optimum irradiance.

iii) The diameter of the bubble is made greater than $2.5 \mathrm{~mm}$ for better mass transfer.

iv) The gas volume was assumed to be $20 \%$ of the liquid volume, and the PBR is square at the front.

The main objective of this part was to find feasible initial conditions based on the best case; the design method depends on this initial condition to find feasible solutions. Table 1 shows the employed model parameters. The values were taken from different authors (Carvalho \& Malcata, 2001; Kurano \& Miyachi, 2005; Greenwald et al., 2012; Chisti, 1989) or calculated assuming that we operate at the assumed conditions previously described. If it reaches steady state and establishes optimal growth rate conditions, the analysis will be conducted like a single chemostat without biomass input, i.e., equation 13, since it is the operation that would give higher productivity. This analysis is shown in equations 13 and 14.

$\mu=D$

$r_{s}=D\left(\mathrm{CO}_{2 i n}-\mathrm{CO}_{2}\right)+K_{L} a \cdot\left(\mathrm{CO}_{2}{ }^{*}-\mathrm{CO}_{2 o u t}\right)$

The flux was found through the dilution equating to the specific growth rate in optimal conditions for a continuous system. Also, a volume of $150 \mathrm{~L}$ is assumed.

Table 1. Model parameters.

\begin{tabular}{|c|c|c|}
\hline \multicolumn{3}{|c|}{ Parameters } \\
\hline$\mu_{\text {max }}\left(h^{-1}\right)$ & 0.134 & (Kurano \& Miyachi, 2005) \\
\hline$\mu_{\mathrm{opt}}\left(\mathrm{h}^{-1}\right)$ & 0.12 & \\
\hline$I_{\text {opt }}\left(K W / \mathrm{m}^{2}\right)$ & 0.11979 & (Kurano \& Miyachi, 2005) \\
\hline$I_{0}\left(K W / m^{2}\right)$ & 0.7 & \\
\hline $\mathrm{K}_{\mathrm{s}}(\mathrm{bar})$ & 0.00048 & (Kurano \& Miyachi, 2005) \\
\hline $\mathrm{K}_{\mathrm{i}}($ bar $)$ & 0.31 & (Kurano \& Miyachi, 2005) \\
\hline$\alpha$ & 5.48 & (Berberoglu et al., 2009) \\
\hline$\rho_{L}\left(\mathrm{Kg} / \mathrm{m}^{3}\right)$ & 997 & \\
\hline$V\left(m^{3}\right)$ & 0.15 & \\
\hline$D_{\mathrm{CO} 2}\left(\mathrm{~m}^{2} / \mathrm{h}\right)$ & $7.0567 \times 10-6$ & (Carvalho \& Malcata, 2001) \\
\hline$\mu_{L}(\mathrm{Kg} / \mathrm{h} * \mathrm{~m})$ & 3.204 & \\
\hline$d_{B}(m)$ & 0.005 & \\
\hline $\mathrm{CO}_{2 \text { in }}\left(\mathrm{kg} / \mathrm{m}^{3}\right)$ & 0.3 & \\
\hline $\mathrm{CO}_{2 \mathrm{gin}}\left(\mathrm{kg} / \mathrm{m}^{3}\right)$ & 0.9 & \\
\hline $\mathrm{Y}_{\mathrm{x} / \mathrm{CO}_{2}}\left(\mathrm{~kg} \mathrm{X} / \mathrm{kg} \mathrm{CO} \mathrm{CO}_{2}\right)$ & 0.45 & (Ruiz, 2011) \\
\hline$V_{+}(\mathrm{m} / \mathrm{h})$ & 118.8 & \\
\hline$V_{g}\left(m^{3} / h\right)$ & 0.03 & \\
\hline $\mathrm{CO}_{2 \text { out }}\left(\mathrm{kg} / \mathrm{m}^{3}\right)$ & $1.52 * \mathrm{pCO}_{2}$ & \\
\hline
\end{tabular}

The obtained solution defines some PBR dimensions, flows (total and gas), carbon dioxide concentrations in the liquid and gas and biomass concentration (Table 2).

\section{Biomass concentration in PBR units with constant growth kinetics.}

PBR design has a recirculating flow from the last reactor that mixes with the fresh medium and feeds the first reactor. The total PBR system is formed by a set of continuous flow bioreactors in series, such that the 


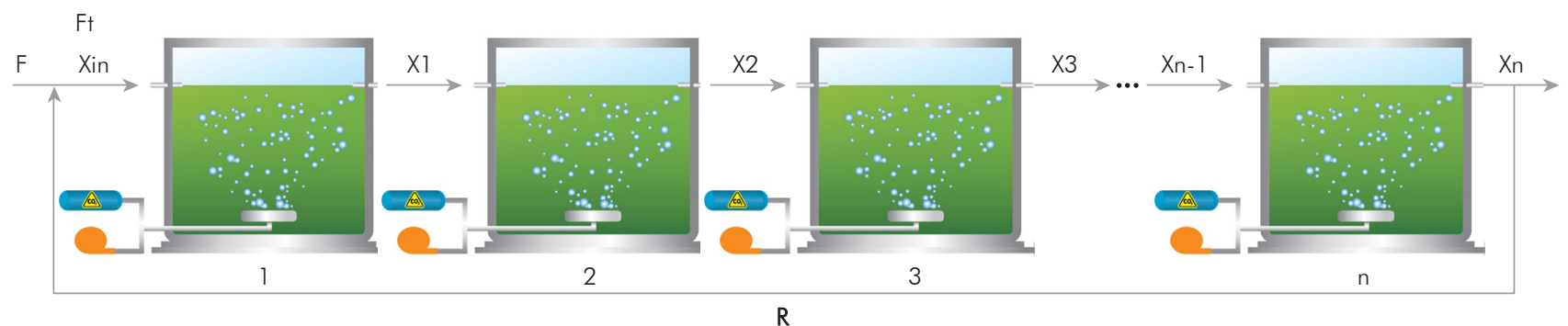

Figure 2. Continuous PBR in series with recirculation system, recirculation flow from $n$-th system is mixed with fresh medium before the first system.

biomass leaving the first reactor is the input to the next reactor. Moreover, the diluted substrate concentration from the first reactor is the concentration input to the second. This is repeated sequentially for each PBR in series as it is shown in Figure 2.

The respective mass balances were established and then a set of linear equations were organized in a nxn matrix, where $\mathrm{n}$ is the number of reactors. In addition, the growth rate was the same for all reactors. Although this is not the real situation, it is an assumption made to obtain an initial condition of biomass concentration on each PBR unit in series.

$\left[\begin{array}{llll}\mu-D & 0 \ldots & 0 & 0 \\ D & \mu-D & 0 & 0 \\ 0 & D & \ddots & 0 \\ 0 & 0 \ldots & D & \mu-D\end{array}\right] \cdot\left[\begin{array}{c}X_{1} \\ X_{2} \\ \vdots \\ X_{n}\end{array}\right]=\left[\begin{array}{c}-D X_{i n} \\ 0 \\ \vdots \\ 0\end{array}\right]$

The linear equation system (15) is solved to obtain the biomass concentration in every PBR unit $\left(X_{0}=\left[X_{1}, X_{2}, \ldots\right.\right.$ ,$\left.\left.X_{n}\right]^{T}\right)$; this linear equation system facilitates the entire system solution. The biomass concentration results are shown in Figure (3). Biomass concentration values were very high because an optimum case was assumed. Since microalgae specific growth rate is the maximum possible, the results reach a high biomass concentration value. However, specific growth velocity depends on biomass concentration and nutrients availability, which will produce a decrease in the growth rate. Usual biomass concentration in this kind of PBRs culture is into the $100 \mathrm{~g} / \mathrm{m}^{3}$ to $600 \mathrm{~g} / \mathrm{m}^{3}$ (Concas, Steriti, Pisu \& Cao, 2014; Concas, Pisu \& Cao, 2013). That is why it is necessary to estimate the specific growth rate in every PBR unit.

\section{Estimating the Specific Growth Rate.}

The biomass concentration profile obtained in the previous section $\left(X_{0}\right)$ by equating 15 solutions, (Figure 3 ) is used to evaluate the new values of specific growth rate for each reactor with equations 2, 6 and 8 . As the amount of biomass increases on each unit, the biomass affects carbon dioxide concentration and in turn, the specific growth rate and also the lighting in the PBR. Each PBR unit biomass concentration value is used in the above equations generating a variable specific growth rate in each unit $\left(\mu_{1}, \mu_{2}, \ldots, \mu N\right)$. Different dioxide concentration values in each unit are calculated too.

\section{Biomass Concentration in PBR units with new Growth Kinetics}

Using previous specific growth rate results with the mass balance equations modified and reassembled in the new linear system carries

$$
\left[\begin{array}{llll}
\mu_{1}-D & 0 \ldots & 0 & 0 \\
D & \mu_{2}-D & 0 & 0 \\
0 & D & \ddots & 0 \\
0 & 0 \ldots & D & \mu_{n}-D
\end{array}\right] \cdot\left[\begin{array}{c}
X_{1} \\
X_{2} \\
\vdots \\
X_{n}
\end{array}\right]=\left[\begin{array}{c}
-D X_{i n} \\
0 \\
\vdots \\
0
\end{array}\right]
$$

In this way the new matrix is constructed and the linear equations are subsequently solved. As a result, new biomass concentration values $\left(X_{I}=\left[X_{1}, X_{2}, \ldots, X_{n}\right]^{T}\right)$ for every PBR unit are calculated with the variation of the specific growth rate on each PBR; this matrix equation facilitates finding a solution.

The algorithm was solved for the system of equations through MATLAB ${ }$, as this software is widely used and accepted by the scientific community for its performance in the treatment of matrices, allowing for a wide reproduction of the results. The solution of the system of equations was resolved with the "fsolve" function, using the initial conditions for 10 reactors and the options for their operation; these requirements were found across of the OPTIMSET function, with a maximum of one thousand iterations. 


\section{Iterate until Error < Tolerance}

Now we can calculate the error using the initial biomass concentration vector $X_{0}$ and the new probable $X_{1}$. The error can be calculated as:

$$
\text { error }=\left|X_{1}-X_{0}\right|
$$

Then the new assumption is used as the initial condition to estimate new specific growth rate values in step 3. The iteration step is repeated until convergence is reached by evaluating the difference between biomass concentration initial values and the new guessed solution, defining a tolerance of $1 \times 10^{-16}$. Final results are showed in Figures 3, 4 and 5.

\section{RESULTS AND ANALYSIS.}

The PBR pre-design was the first step in order to set several design variables. The PBR was set at a volume in $150 \mathrm{~L}$, using optimal conditions to evaluate the flux, PBR depth, gas flow and gas/liquid Carbon Dioxide concentration. This first result is showed in Table 2.

Table 2. System results in optimum condition

\begin{tabular}{|cc|}
\hline $\mathrm{CO}_{2 s}(\mathrm{~g} / \mathrm{L})$ & 0.0477 \\
\hline $\mathrm{F}(\mathrm{m} 3 / \mathrm{h})$ & 0.0165 \\
\hline $\mathrm{L}(\mathrm{m})$ & 0.0914 \\
\hline $\mathrm{CO}_{2 \mathrm{GS}}(\mathrm{g} / \mathrm{L})$ & 0.0793 \\
\hline $\mathrm{F}_{\mathrm{g}}(\mathrm{m} 3 / \mathrm{h})$ & 0.0714 \\
\hline
\end{tabular}

The concentration values changed once the method was performed. The PBR pre-design variables were used to evaluate the matrix equation (16) and the biomass concentration in each unit. The concentration profile was obtained and it is shown in Figure 2.

Figure 3 shows biomass concentration if the specific growth rates are constant and not affected by the PBR variables. The specific growth rate does not vary from PBR to PBR. The biomass concentration values represent an unreal scenario because real growth is limited by the medium variables. High biomass concentration was obtained because it was assumed as an optimal growth rate; in spite of it, is not a real situation. However, these results help us as a first guess or initial condition to approach to the real solution.

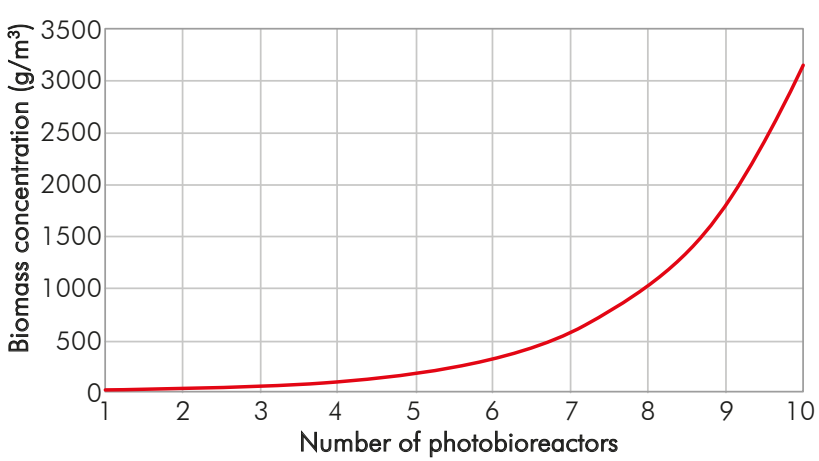

Figure 3. Biomass concentration at the outflow of each bioreactor: assuming that specific growth rate does not change in the system $/ \mu$ constant).

After obtaining the concentration of biomass with constant specific growth rate (Figure 3) and replacing these values in the equations associated with the biomass concentration (equations 2, 6 and 8), a variable specific growth rate and $\mathrm{CO}_{2}$ concentrations on each unit were obtained. Specific growth rate was decreased while numbers of PBR units were increased. When biomass concentration increases, less average light and low liquid $\mathrm{CO}_{2}$ concentration is produced.

Afterwards, the variable values of specific growth rate on each PBR unit are introduced into the new matrix (equation 18), generating a new concentration profile. Then the iteration process is performed until the error (equation 19) is lower than $1 \times 10^{-16}$. The results are shown in Figures 4, 5 and 6.

The initial and final concentration is used to calculate the reflux $R$ and the inlet flow $F$; biomass and total mass balances at the mixing point show that $R=4 \mathrm{~L} / \mathrm{h}$ and inlet flow is $F=29 \mathrm{~L} / \mathrm{h}$. This considering that the $F_{t}$ is going to double its value that yielded by the optimal system.

Figure 5 represents the solution of biomass concentration for each PBR. In this case the effects of carbon dioxide and the irradiance variation are taken into account as the microalgae growth takes place. Figure 5 demonstrates almost linear growth. Also, high concentrations are reached and the system seems stable in all PBRs. Figure 4 shows that the specific growth rate decreases but in a smaller proportion to each reactor, without reaching complete inhibition or shortage. 


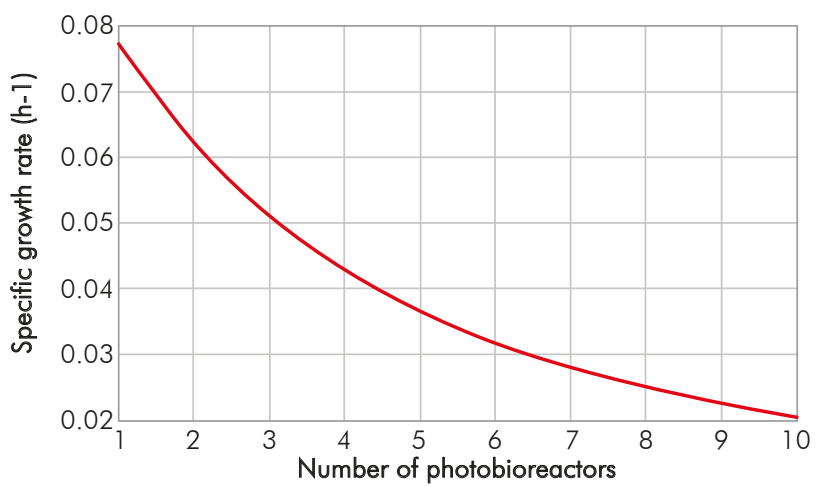

Figure 4. Specific growth rate into each PBR: $\mu$ is variable because is limited by the PBR variables.

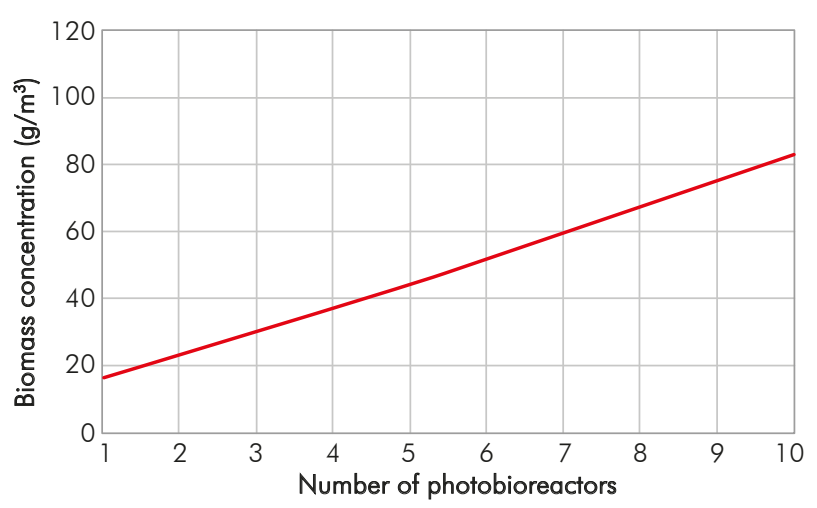

Figure 5. Biomass concentration at the oufflow of each bioreactor: using variable specific growth rate.

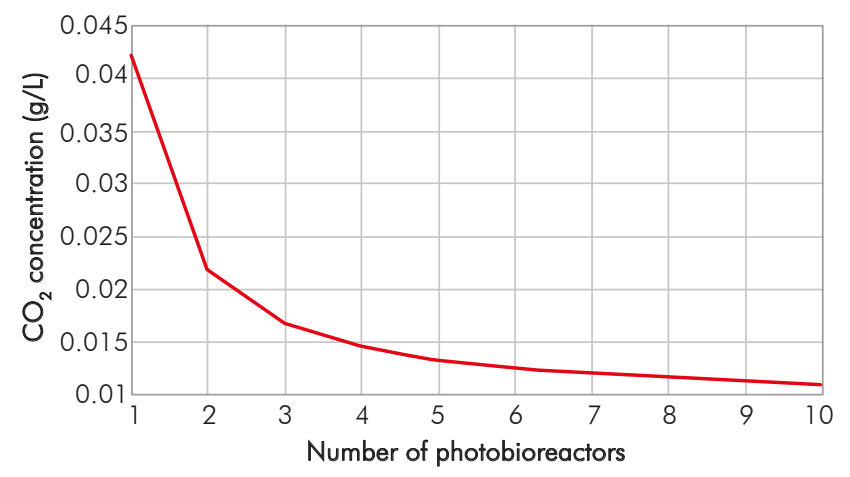

Figure 6. $\mathrm{CO}_{2}$ concentration in the liquid oufflow per PBR, high dense cultures consumes more $\mathrm{CO}_{2}$ into the PBR, reducing carbon source availability.

The dissolved carbon dioxide concentration in liquid outflow per PBR is shown in Figure 6. This parameter decreases as it moves from PBR to PBR; this is due to the increasing numbers of cells in each unit. At each stage they demand more nutrients and since the gas flow is constant, the concentration of carbon dioxide in the liquid decreases. Despite this profile the cells continue to grow because they still have enough food. Only when food concentration reaches zero, the biomass concentration profile will begin to decline.

As a result it was found that 10 reactors are required. The PBR flat plate unit should have a volume of $150 \mathrm{~L}$, where dimensions are $9.15 \mathrm{~cm}$ depth, $1.28 \mathrm{~m}$ long and $1.28 \mathrm{~m}$ high. Final productivity is $15.46 \mathrm{~g} / \mathrm{m}^{3} \mathrm{~h}$.

To minimize uncertainty, artificial radiation was used as it remains constant over time. We evaluate a different case, where the light source is higher $\left(\mathrm{I}_{0}=1.48 \mathrm{~kW} / \mathrm{m}^{2}\right)$, and assuming the use of artificial light.

The new predesign case changes the dimensions of the PBR (depth $19.6 \mathrm{~cm}$, width and height $89 \mathrm{~cm}$ ) and the conditions of PBR as gas flow $\left(F_{g}\right)$; initial biomass concentration $\left(X_{i n}\right)$ and carbon dioxide gas concentration $\left(\mathrm{CO}_{2 \mathrm{Gs}}\right)$ were $104.7 \mathrm{~L} / \mathrm{h}, 0.011 \mathrm{~g} / \mathrm{L}$ and $0.1153 \mathrm{~g} / \mathrm{L}$, respectively. Biomass concentration results are shown in Figure 7. The graphic demonstrates that biomass concentration is lower than the previous case. This is possible because PBR flat plate unit is larger than the previous one and it could affect the growth rate.

The gas flow that has the carbon source for the microalgae is initially constant. With the increase of biomass concentration, more $\mathrm{CO}_{2}$ would be necessary and might become a limiting growth nutrient. We evaluated what would have happen if the gas flow $\left(F_{g}\right)$ was increased at the entrance of each PBR gradually. The first reactor had a nominal aeration flow, but the second one had an increase of $2 \mathrm{~L} / \mathrm{h}$ in the nominal flow. The same increase is performed in the subsequent flat panel PBRs. The result of the simulation is shown in Figures 7 and 8. Thus the final biomass concentration to elapse $10 \mathrm{PBR}$ is $110 \mathrm{~g} / \mathrm{m}^{3}$ resulting in a productivity of $21.26 \mathrm{~g} / \mathrm{m}^{3} \mathrm{~h}$. The concentration is greater than that shown in Figure 4 since each PBR has more food availability for microalgae due to the increase of the gas flow. The $\mathrm{CO}_{2}$ concentration in the liquid will be higher because the $\mathrm{CO}_{2}$ in the gas comes out faster. However, we did not consider the effect on $\mathrm{pH}$ which could have a negative impact on microalgae growth. 


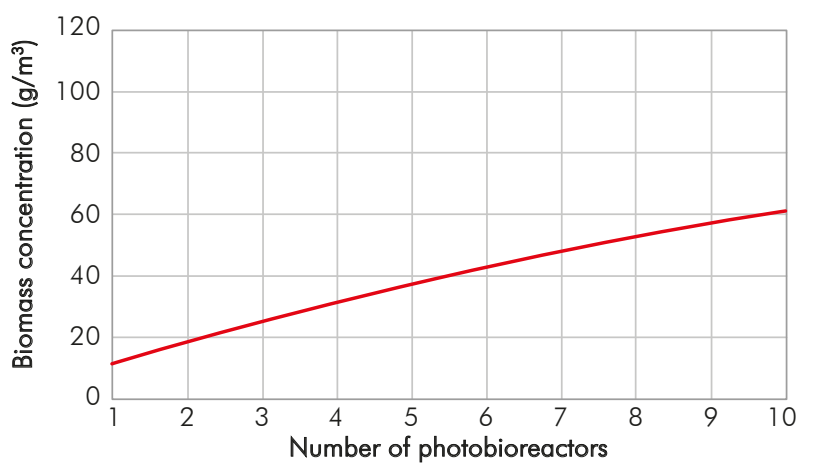

Figure 7. Biomass concentration at the oufflow of each bioreactor with artificial light.

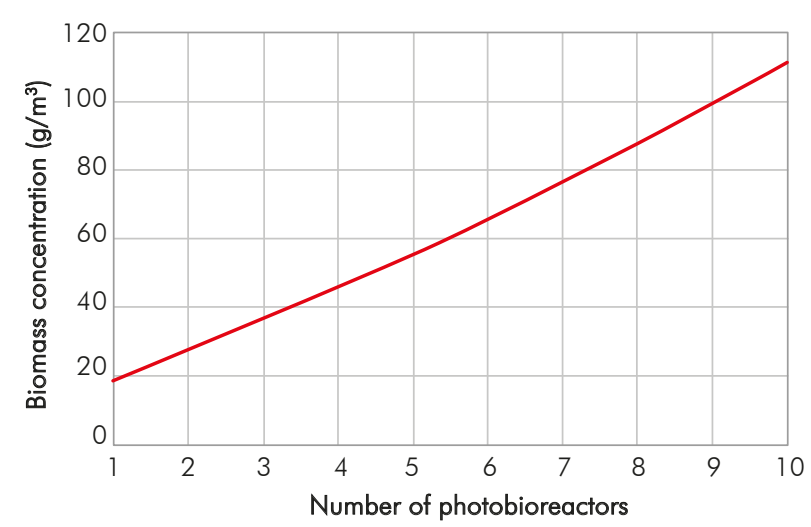

Figure 8. Biomass concentration at the outflow of each bioreactor varying the gas flow feeding: more carbon source is used by the culture which improves the biomass productivity.

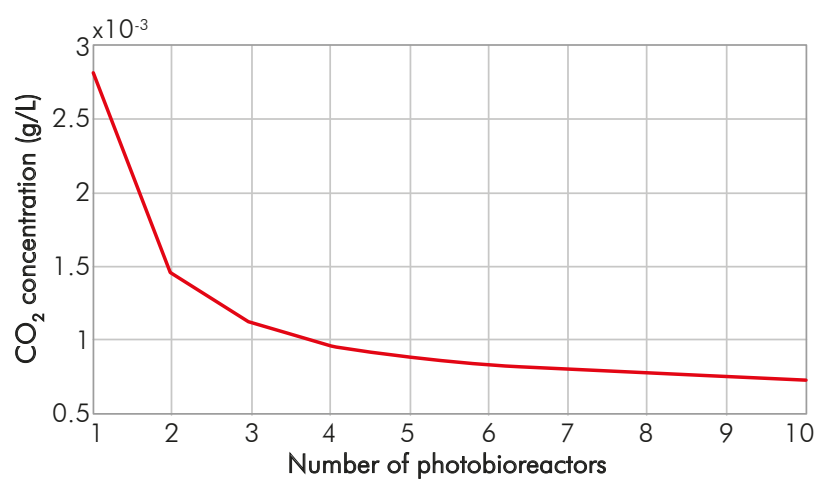

Figure 9. $\mathrm{CO}_{2}$ concentration in the liquid outflow per PBR varying the gas flow feeding: carbon source is consumed as biomass concentration becomes higher.

Figure 8 shows that $\mathrm{CO}_{2}$ concentration is lower than in the previous scenarios due to high microalgae concentration consuming carbon dioxide faster. In other words, as the $\mathrm{CO}_{2}$ is fed in larger quantities; it is also high consumed because of the high biomass concentration.
Previous simulation tells us that the obtained solution from the method agrees with the process's physical reality. This method can be used to design real PBR in series with recirculation. Moreover, design results are promising to be implemented in a real continuous PBR system. Since the model has not been validated yet, the result must be analyzed with care.

Comparing some values from literature, our results are lower than the actual reports (Bosma et al., 2014; Olivieri, Salatino \& Marzocchella, 2013); for example, concentration reported in Bosma et al. (2014) expects a biomass concentration between $200 \mathrm{~g} / \mathrm{m}^{3}$ to $5000 \mathrm{~g} / \mathrm{m}^{3}$, the values reported are obtained by different kinds of PBRs from the AlgaePARC®. Moreover, Olivieri et al. (2014) reports that biomass concentration is really high in SUBITEC PBR ${ }^{\circledR}$ ranging from $2000 \mathrm{~g} / \mathrm{m}^{3}$ to 5000 $\mathrm{g} / \mathrm{m}^{3}$. Comparing these results with our design we can see that the obtained design can manage realistic values.

\section{CONCLUSIONS}

- Industrial application of PBR for microalgae culture is still a difficult task to fulfill, because PBR construction and operation costs are high and productivity performance is low. Additionally, the scale up of PBR is a hard task, sometimes impossible to achieve. One way to improve productivity is by using continuous PBRs, but again, we would need bigger PBR that cannot be constructed in this moment. We propose the alternative use of several PBRs in series. The main idea is to use small PBRs in series that would work in a continuous way, improving their productivity performance. Mathematical models were built to establish multi-phenomena interactions between the important variables, light, mass transfer and growth kinetics. However, the obtained model is very complex to analyze. This work shows a simple methodology used to design continuous PBRs in series with recirculation, composed by several flat panel reactors. The methodology employs previous PBR knowledge to estimate an initial condition. Then the model is split between a set of linear equations system and a set of nonlinear equations system. An iterative method is applied to obtain the final solution.

- The method used helped us to obtain a reliable result, because the direct solution of the equation using 
numerical methods was very dependent upon the initial conditions. We analyzed the system design and found that it is possible to improve productivity using several flat plate PBRs in series with recirculation. Then, when changing some conditions, we found that the design method can deal with the complexity of the system and predicts, in the real physical sense the possible changes the PBR could have. i.e. the method solutions agree with the expected behavior.

\section{ACKNOWLEDGES}

Authors acknowledge the National University of Colombia (Universidad Nacional de Colombia) and Mines Faculty (Facultad de Minas), which made this work possible.

\section{REFERENCES}

Acién Fernández, F. G., Fernández Sevilla, J. M., Sánchez Pérez, J. A., Molina Grima, E. \& Chisti, Y. (2001) Airlift -driven external-loop tubular photobioreactors for outdoor production of microalgae: assessment of design and performance, Chemical Engineering Science, Vol 56, pp. 2721-2732, doi:10.1016/S0009-2509(00)00521-2.

Barsanti, L. \& Gualtieri, P. (2006) Algae Anatomy, Biochemistry, and Biotechnology, Taylor \& Francis Group, USA.

Béchet, Q., Shilton, A. \& Guieysse, B. (2013) Modeling the effects of light and temperature on algae growth : State of the art and critical assessment for productivity prediction during outdoor cultivation, Biotechnology Advances, Vol 31, pp 1648-1663, doi:10.1016/j.biotechadv.2013.08.014.

Berberoglu, H., Gómez, P. S. \& Pilon, L. (2009) Radiation characteristics of Botryococcusbraunii Chlorococcum littorale, and Chlorella sp. used for $\mathrm{CO}_{2}$ fixation and biofuel production, Journal of Quantitative Spectroscopy \& Radiactive Transfer, Vol 110, pp. 1879-1893, doi:10.1016/j. jqsrt.2009.04.005.

Bosma, R., de Vree, J. H., Slegers, P. M., Janssen, M., Wijffels, R. H. \& Barbosa, M. J. (2014) Design and Construction of the microalgal pilot facility AlgaePARC, Algal Research, Vol 6, Part B, pp. 160-169, doi:10.1016/j.algal.2014.10.006.

Bosma, R., de Vree, J. H., Slegers, P. M., Janssen, M., Wijffels, R. H. \& Barbosa, M. J. (2014) Design and construction of the microalgal pilot facility AlgaePARC, Algal Research, Vol 6, pp. 160-169, doi:10.1016/j.algal.2014.10.006.

Bouallagui, H., Touhami, Y. \& Hanafi, H. (2013) Performances comparison between three technologies for continuous ethanol production from molasses, Biomass and Bioenergy, Vol 48, pp. 25-32, doi:10.1016/j.biombioe.2012.10.018.

Breuer, G., Lamers, P. P., Janssen, M., Wijffels, R. H. \& Martens, D. E. (2015) Opportunities to improve the areal oil productivity of microalgae, Bioresource Technology, Vol 186, pp. 294-302, doi:10.1016/j.biortech.2015.03.085..

Carvalho, A. P. \& Xavier Malcata, F. (2001) Transfer of carbon dioxide within cultures of microalgae: plain bubbling versus hollow-fiber modules, Biotechnology Progress, Vol. 17, No. 2, pp 265-272, doi: 10.1021/bp000157v.

Carvalho, A. P., Silva, S. O., Baptista, J. M. \& Malcata, F. X. (2011) Light requirements in microalgal photobioreactors: an overview of biophotonic aspects, Applied Microbiology Biotechnology, Vol 89, pp1275-1288, doi:10.1007/s00253010-3047-8.

Chisti, Y. (1989) Airlift bioreactors, Elsevier applied biotechnology series. Elsevier Science Publishers Ltd.

Concas, A. Steriti, A., Pisu, M. \& Cao, G. (2014) Comprehensive modeling and investigation of the effect of iron on the growth rate and lipid accumulation of Chlorella vulgaris cultured in batch photobioreactors, Bioresource Technology, Vol 153, pp. 340-350, doi:10.1016/j.biortech.2013.11.085..

Concas, A., Pisu, M. \& Cao, G. (2013) Mathematical Modelling of Chlorella Vulgaris Growth in Semi-Batch Photobioreactors Fed with Pure $\mathrm{CO}_{2}$, Chemical Engineering Transation, Vol 32, pp. 1021-1026, doi:10.3303/ ACOS1311013.

Fernándes, B. D., Mota, A., Teixeira, J. A. \& Vicente, A. A. (2015) Continuous cultivation of photosynthetic microorganisms: Approaches, applications and future trends, Biotechnology Advances, Vol. 33, Issue 6, Part 2, pp. 1228-1245, doi:10.1016/j.biotechadv.2015.03.004.

Fernández, I., Acién, F. G., Berenguel, M. \& Guzmán, J. L. (2014) First principles model of tubular photobioreactor for microalgal production, Industrial and Engineering Chemistry Research, Vol 53, Issue 27, pp. 11121-11136, doi: 10.1021/ie501438r. 
Gadkar, K. G., Doyle F. J. III, Crowley, T. J. \& Varner, J. D. (2003) Cybernetic model predictive control of a continuous bioreactor with cell recycle, Biotechnology Progress, Vol. 19, pp. 1487-1497, doi:10.1021/bp025776d.

García Camacho, F., Gallardo Rodríguez, J.J., Sánchez Mirón, A. \& Belarbi, E. H. (2011) Photobioreactors scale-up for a shear-sensitive dinoflagellate microalgae, Process Biochemistry, Vol. 46, pp. 936-944, doi:10.1016/j. procbio.2011.01.005 .

Greenwald, E., Gordon, J. M. \& Zarmi, Y. (2012) Physics of ultra-high bioproductivity in algal photobioreactors, Applied Physics Letters, Vol 100, American Physical Society's Open Access Journal, 143703, doi:10.1063/1.3701168.

Janssen, M., Tramper, J., Mur, L.R. \& Wijffels, R. H. (2002) Enclosed outdoor photobioreactors: light regime, photosynthetic efficiency, scale up, and future prospects, Biotechnology Bioengineering, Vol 81, pp 193-210, 2002, doi:10.1002/bit.10468.

Kommareddy, A. \& Anderson, G. (2003) Study of light as a parameter in the growth of algae in a Photo-Bio-Reactor (PBR), ASAE Annual International Meeting Presentation 034057, Las Vegas, USA.

Kommareddy, A. \& Anderson, G. (2004) Study of Light requirements of a photobioreactor, North Central ASAE/ CSAE Conference Presentation MB04-111, Winnipeg, USA.

Kurano, N. \& Miyachi, S. (2005) Selection of microalgal growth model for describing specific growth rate-light response using extended information criterion, Journal of Bioscience and Bioengineering, Vol. 100, No. 4, pp 403408, doi:10.1263/jbb.100.403.

Lehr, F. \& Posten, C. (2009) Closed photobioreactors as tools for biofuel production, Current opinion in Biotechnology, Vol. 20, pp. 280-285, doi:10.1016/j.copbio.2009.04.004.

Molina Grima, E., Acién Fernández, F. G., García Camacho, F. \& Chisti, Y. (1999) Photobioreactors: light regime, mass transfer, and scale up, Journal of Biotechnology, Vol 70, pp 231-247, doi:10.1016/S0168-1656(99)00078-4.

Molina Grima, E., Acién Fernández, F. G., García Camacho, F., Camacho Rubio F. \& Chisti, Y. (2000) Scale-up of tubular photobioreactors, Journal of applied phycology, Vol 12, pp. 355-368, doi:10.1023/A:1008110819338 .

Molina Grima, E., García Camacho, F., Sánchez Pérez, J. A., Acién Fernández, F. G. \& Fernández Sevilla, J. M. (1997) Evaluation of photosynthetic efficiency in microalgal cultures using averaged irradiance, Enzyme and Microbial Technology, Vol 21, pp 375-381, doi:10.1016/S01410229(97)00012-4.

Nielsen, J., Villadsen, J. \& Lidén, G. (2003) Bioreaction Engineering Principles. Kluwer Academic/Plenum Publishers, Second edition.

Olivieri, G., Salatino, P. \& Marzocchella, A. (2013) Advances in photobioreactors for intensive microalgal production : configurations, operating strategies and applications, Journal of Chemical Technology and Biotechnology, Vol 89, pp. 178-195, doi:10.1002/jctb.4218.

Posten, C. (2009) Design principles of photobioreactors for cultivation of microalgae, Engineering Life Science, Vol 9, No 3, pp 165-177, doi:10.1002/elsc.200900003.

Quinn, J. C., Turner, C. W. \& Bradley, T. H. (2015) Scale up of flat plat photobioreactors considering diffuse and direct light characteristics, Biotechnology and bioengineering, Vol. 109, pp. 363-370, doi:10.1002/bit.23324.

Ruiz A. (2011) Puesta en marcha de un cultivo de microalgas para la eliminación de nutrientes de un agua residual urbana previamente tratada anaeróbicamente. Master universitario en ingeniería hidráulica y medio ambiente, Universidad Politécnica de Valencia, Valencia, España. Número de páginas 102 .

Schügerl, K., Rehm, H. J., Reed, G., Pühler, A. \& Stadler, P. J. (1991) Biotechnology, Volume 4 Measuring, modeling, and control. VCH Publishers Inc., Second edition, New York (USA).

Sierra, E., Acién, F. G., Fernández, J. M., García, J. L., González, C. \& Molina Grima, E. (2008) Characterization of a flat plate photobioreactor for the productión of microalgae, Chemical Engineering Journal, Vol 138, pp 136-147, doi:10.1016/j.cej.2007.06.004. 


\section{AUTHORS}

\section{Sandra Vargas}

Affiliation: Grupo de Automática de la Universidad Nacional

GAUNAL. Universidad Nacional de Colombia. Facultad de Minas.

Medellín. Colombia

e-mail: salvargasdi@unal.edu.co

\section{César Augusto Gómez Pérez}

Affiliation: Grupo de Automática de la Universidad Nacional GAUNAL. Universidad Nacional de Colombia. Facultad de

Minas. Medellín. Colombia

e-mail: cagomez@unal.edu.co

\section{Jairo Espinosa}

Affiliation: Grupo de Automática de la Universidad Nacional GAUNAL. Universidad Nacional de Colombia. Facultad de

Minas. Medellín. Colombia

e-mail: jespinov@unal.edu.co 


\section{NOMENCLATURE}

$\mu \quad$ Specific growth rate

$\mu_{\max } \quad$ Maximum specific growth rate

I Light intensity

$I_{\text {opt }} \quad$ Light intensity where $\mu=\mu_{\max }$

$I_{0} \quad$ Irradiance of the light source

$p \mathrm{CO}_{2}$ Partial pressure of $\mathrm{CO}_{2}$

$K_{s} \quad$ Saturation constant

$K_{i} \quad$ Inhibition constant

$X_{e} \quad$ Biomass concentration at the entrance

$X_{s} \quad$ Biomass concentration at the outlet

$\mathrm{CO}_{2}{ }^{*}$ Concentration of $\mathrm{CO}_{2}$ in balance

$\mathrm{CO}_{2 \mathrm{e}}$ Concentration of $\mathrm{CO}_{2}$ in the inlet liquid

$\mathrm{CO}_{2 \mathrm{~s}}$ Concentration of $\mathrm{CO}_{2}$ into the liquid outlet

$\mathrm{CO}_{2 \mathrm{ge}}$ Concentration of $\mathrm{CO}_{2}$ in the inlet gas

$\mathrm{CO}_{2 g s}$ Concentration of $\mathrm{CO}_{2}$ in the gas at the outlet

Kla Constant mass transfer

$r_{s} \quad$ Substrate consumption rate

$D \quad$ Dilution

$F \quad$ Inlet Flow before mixing point

$R \quad$ Recirculation flow

$V \quad$ Volume of liquid

$F_{g} \quad$ Gas Flow

$V_{g} \quad$ Volume of gas

$\alpha \quad$ Coefficient of absorptivity

$L \quad$ Depth photobioreactor

$\varepsilon \quad$ Gas Hold-up

$\mu_{L} \quad$ Viscosity of the liquid

$\rho_{L} \quad$ Density of the liquid

$d_{B} \quad$ Bubble diameter

$V_{t} \quad$ Individual bubble speed

$\mathrm{D}_{\mathrm{CO}_{2}} \quad \mathrm{CO}_{2}$ diffusivity

$X_{n} \quad$ Biomass concentration in the reactor $n$

$F_{t} \quad$ Inlet flow at each PBR unit 
